\title{
Use of monoclonal antibodies for detection of infectious pancreatic necrosis virus by the enzyme- linked immunosorbent assay (ELISA)
}

\author{
J. Domínguez ${ }^{1}$, R. P. Hedrick ${ }^{2}$, J. M. Sánchez-Vizcaino ${ }^{1}$ \\ ${ }^{1}$ INIA, Dpto de Sanidad Animal, Embajadores 68, E-28012 Madrid, Spain \\ ${ }^{2}$ School of Veterinary Medicine, University of California, Davis, California 95616, USA
}

\begin{abstract}
An enzyme-linked immunosorbent assay (ELISA) has been developed for identification of the Sp strain of infectious pancreatic necrosis virus (IPNV). This assay employed 2 monoclonal antibodies directed against 2 non-overlapping epitopes of the minor structural viral protein. It was used to demonstrate the virus antigen in cell cultures and was able to detect $10 \mathrm{ng} \mathrm{ml}^{-1}$ of purified virus or $10^{4}$ $\mathrm{TCID}_{50} \mathrm{ml}^{-1}$ in tissue culture fluid. The assay could be reduced to one step and be performed within 90 min with good sensitivity. No antigenic variation, affecting the epitopes recognized by these monoclonal antibodies, was observed on 17 IPNV isolates of Sp serotype tested.
\end{abstract}

\section{INTRODUCTION}

Infectious pancreatic necrosis virus (IPNV) is a member of the Birnaviridae and can cause high mortality in young salmonid fish. The IPNV particle contains a bisegmented, double-stranded RNA genome within a medium-size unenveloped icosahedral capsid (Pilcher \& Fryer 1980).

Three main serotypes of IPNV ( $\mathrm{Sp}, \mathrm{Ab}$, and $\mathrm{VR}_{299}$ ) have been defined in the past by cross-neutralization assays using polyclonal antisera (Ahne 1981). Recently, Hill \& Way (1988) proposed a serotyping scheme of 2 serogroups with 9 serotypes in the first serogroup, including serotypes $\mathrm{Sp}, \mathrm{Ab}$, and $\mathrm{VR}_{299}$

Rapid and accurate diagnosis of IPNV infection is critical to the control of the virus because trout surviving infections as juveniles may become lifelong carriers and shed live virus (Yamamoto 1975). Neutralization assay is the most reliable and most widely used diagnostic procedure because of its sensitivity. However, this assay is time-consuming and laborious. More rapid serological techniques for antigen detection such as immunofluorescence or immunoperoxidase staining of infected cells (Piper et al. 1973, Nicholson \& Henchal 1978), coagglutination (Kimura et al. 1984) or immunoblotting (McAllister \& Schill 1986) have been used but they have not gained widespread acceptance.

The use of enzyme-linked immunosorbent assay
(ELISA) for detection of IPNV has been described by several authors with sensitivity levels ranging from $10^{2}$ to $10^{5.5} \mathrm{TCID}_{50}(50 \%$ tissue culture infective dose) per $0.1 \mathrm{ml}$ of culture fluid, depending largely on the quality of the polyclonal antisera used (Nicholson \& Caswell 1982, Dixon \& Hill 1983, Hattori et al. 1984, Rodack et al. 1988).

In this report we described the use of 2 monoclonal antibodies (Mab) directed against the minor structural viral protein (VP3) in a biotin-avidin amplified ELISA for the detection of serotype Sp of IPNV.

\section{MATERIAL AND METHODS}

Viruses. The Sp strain of IPNV was isolated from rainbow trout Oncorhynchus mykiss from Spain (Jimenez et al. 1988). The Ab strain was obtained from B. J. Hill, and the $V_{2} R_{29}$ isolate from ATCC (American Type Culture Collection). All isolates were cloned, by end point dilution, 3 times before use.

Purification of virus. Virus purification was similar to that previously described for IPNV (Hedrick et al. 1983). Briefly, virus isolates were propagated using the Chinook salmon Oncorhynchus tshawytscha embryo cell line (CHSE-214) (ATCC CRL 1691). Infected monolayers were maintained at $14{ }^{\circ} \mathrm{C}$ in minimal essential medium (MEM) supplemented with Earle's salts, fetal 
calf serum (5\% v/v), $2 \mathrm{mM}$ L-glutamine, $50 \mu \mathrm{g} \mathrm{m \textrm {m } ^ { - 1 }}$ streptomycin, and $50 \mathrm{IU} \mathrm{ml}^{-1}$ penicillin (maintenance medium), until the cytopathic effect (CPE) was extensive.

The infected cells were scraped into the supernatant and centrifuged using a $35 \mathrm{Ti}$ rotor at $125000 \times \mathrm{g}$ for 60 min. The pellet was resuspended in $6 \mathrm{ml}$ of TNE buffer (0.01 M Tris- $\mathrm{HCl}, 0.1 \mathrm{M} \mathrm{NaCl}, 0.001 \mathrm{M}$ EDTA, pH 7.2) and $12 \mathrm{ml}$ of Genetron (1,1,2-trichloro-1,2,2-trifluoroethane) (Allied Chemical Co., USA) was added. The mixture was homogenized in a Stomacher for 2 to 3 min and then centrifuged at $700 \times g$ for $10 \mathrm{~min}$. The aqueous phase containing virus was collected and layered on a composite, sucrose-cesium chloride gradient ( $3 \mathrm{ml}$ of $40 \% \mathrm{CsCl}, 3 \mathrm{ml}$ of $30 \% \mathrm{CsCl}$ and $2 \mathrm{ml}$ of $20 \%$ sucrose in TNE) and was centrifuged at $130000 \times g$ for $3 \mathrm{~h}$ using a SW 41 rotor. After centrifugation, the visible band between the 40 and $30 \%$ phases was collected by side puncture. The band was mixed with TNE and pelleted by centrifugation at $130000 \times g$ for $60 \mathrm{~min}$. The pellet was resuspended in TNE and layered onto a $\mathrm{CsCl}$ step gradient $\left(4 \mathrm{ml}\right.$ of $40 \% \mathrm{CsCl}_{1} 3 \mathrm{ml}$ of $30 \%$ $\mathrm{CsCl}, 2 \mathrm{ml}$ of $20 \% \mathrm{CsCl}$ ), and centrifuged overnight at $130000 \times g$. The visible band was collected, pelleted as before, and resuspended in TNE for storage. Protein concentration was determined by the method of Bradford (1979).

Monoclonal antibody (Mab) production. Female $\mathrm{Balb} / \mathrm{C}$ mice were injected intraperitoneally (ip) with $20 \mu \mathrm{g}$ of purified IPNV (Sp strain) emulsified in complete Freund's adjuvant. Nine months later, a second dose of $100 \mu \mathrm{g}$ of purified IPNV in incomplete Freund's adjuvant was given ip. Three weeks later, a third dose of $100 \mu \mathrm{g}$ was given intravenously (iv). On the $3 \mathrm{~d}$ previous to fusion, mice were injected ip and iv daily with $100 \mu \mathrm{g}$ of purified IPNV, according to the method of Stahli et al. (1983).

The spleen cells were fused with the X63 Ag8.653 myeloma cell line following a procedure similar to that described by Kohler \& Milstein (1975).

Culture supernatants from the wells with growing hybridoma colonies were assayed by an indirect ELISA as described below. All hybridomas were cloned by limiting dilution at least twice. The class and subclass of the Mabs were determined by the indirect ELISA technique using rabbit antisera specific for mouse heavy and light chains and peroxidase-conjugated goat-anti-rabbit immunoglobulins (Bio-Rad, Richmond, USA). Cloned hybridomas were injected into pristane primed mice for ascites production (Coll 1987). Mabs from ascites were purified by affinity chromatography on Protein A-Sepharose CL-4B (Pharmacia, Uppsala, Sweden) as described by Ey et al. (1978).

Biotinylation of monoclonal antibodies. For biotinylation, Mabs at concentrations of approximately $1 \mathrm{mg}$ $\mathrm{ml}^{-1}$ were dialyzed into $0.1 \mathrm{M}$ sodium bicarbonate. Biotin N-hydroxysuccinimide ester (Sigma, USA) was dissolved in dimethyl sulfoxide (Merck, Germany) at $1 \mathrm{mg} \mathrm{ml}^{-1}$ and $125 \mu \mathrm{l}$ was added to each ml of antibody solution. The mixture was allowed to stand at room temperature for $4 \mathrm{~h}$ and was dialyzed against phosphate buffered saline (PBS) $(0.01 \mathrm{M}$ phosphate $0.15 \mathrm{M}$ $\mathrm{NaCl}, \mathrm{pH} 7.2$ ). Biotin conjugates were stored at $4{ }^{\circ} \mathrm{C}$ after addition of $0.01 \%$ merthiolate. The conjugates were diluted to the actual working dilution just prior to use.

Indirect ELISA. Dynatech M-129 B ELISA plates were coated with $0.2 \mathrm{\mu g}$ of protein per well of purified virus diluted in PBS by overnight incubation at $4{ }^{\circ} \mathrm{C}$. Plates coated with $1 \%$ bovine serum albumin (BSA) or uninfected CHSE-214 culture fluid extracts were used as controls. Hybridoma supernatants or ascites fluid diluted in dilution buffer (PBS: $0.05 \%$ Tween 20, $1 \%$ BSA, $0.01 \%$ merthiolate) were added and incubated for $1 \mathrm{~h}$ at room temperature. The plates were washed 5 times with tap water containing $0.01 \%$ Tween 20 (washing solution). Subsequently, $100 \mu \mathrm{l}$ of rabbit antimouse Igs conjugated to peroxidase (Biodiagnostic, U.K.) diluted $1 / 1600$ in dilution buffer was added to each well and incubated for $1 \mathrm{~h}$ at room temperature. Following 5 washes with washing solution, $100 \mu \mathrm{l}$ of 1,2 o-phenylenediamine $\left(2 \mathrm{mg} \mathrm{ml}^{-1}\right)$ in $0.1 \mathrm{M}$ citrate buffer, $\mathrm{pH} 5.0$ and $0.03 \% \mathrm{H}_{2} \mathrm{O}_{2}$ was added to each well. Color development was stopped by adding $100 \mu \mathrm{l}$ of $3 \mathrm{~N} \mathrm{H}_{2} \mathrm{SO}_{4}$ after 10 to $15 \mathrm{~min}$. Plates were read at $492 \mathrm{~nm}$ using a Titertek Multiskan (Flow, Ayrshire, U.K.).

Double antibody ELISA. Two kinds of double antibody ELISA tests were used in this study: a 3 step and a one step assay.

Three step assay. Dynatech M-129B ELISA plates were coated with $0.2 \mu \mathrm{g}$ per well of purified 3B12 Mab diluted in PBS by overnight incubation at $4{ }^{\circ} \mathrm{C}$. Plates were washed 5 times with washing solution and incubated for $1 \mathrm{~h}$ at room temperature with $100 \mu \mathrm{l}$ well ${ }^{-1}$ of serial dilutions of IPN-infected CHSE-214 culture supernatant or purified virus in dilution buffer. Similar dilutions of uninfected CHSE-214 culture supernatant were used as controls. After 5 washes with washing solution, plates were incubated for $1 \mathrm{~h}$ at room temperature with $100 \mu \mathrm{l}_{\text {well }}{ }^{-1}$ of a $1 / 1000$ dilution of biotin labelled 2F12 Mab. After 5 more washes, the plates were incubated with $100 \mu \mathrm{l}$ well ${ }^{-1}$ of avidin-peroxidase (Dako, Copenhagen, Denmark) diluted 1/2000 in dilution buffer for $40 \mathrm{~min}$ at room temperature. Plates were washed 5 times and the enzymatic reaction developed as described for indirect ELISA.

One slep assay. Plates coated with 3 B12 Mab were incubated for $90 \mathrm{~min}$ with $200 \mu \mathrm{w}^{-1} \mathrm{l}^{-1}$ of serial dilution of IPN-infected CHSE-214 culture supernatant, 
mixed with biotin labelled 2F12 Mab diluted at 1/2000 and avidin peroxidase diluted at $1 / 4000$. After 5 washes the enzymatic reaction was developed as described for indirect ELISA.

Competition assays for epitope determination. Using the ELISA technique, competitive binding assays were performed with the biotin labelled Mabs against unlabelled Mabs. Plates were coated with purified virus as described for indirect ELISA. The plates were then incubated for $90 \mathrm{~min}$ at room temperature with $200 \mu \mathrm{l}$ of a $1 / 2000$ dilution of biotinylated antibodies $\left(0.5 \mu \mathrm{g} \mathrm{ml}^{-1}\right)$ in dilution buffer containing different concentrations of purified Mabs $\left(3,9,27,83,250 \mu \mathrm{g} \mathrm{ml}^{-1}\right)$. After 5 washes the plates were incubated with $100 \mu$ l well $^{-1}$ of avidin-peroxidase (Dako, Copenhagen, Denmark), diluted $1 / 1000$ in dilution buffer for $1 \mathrm{~h}$ at room temperature. Plates were washed 5 times and the enzymatic reaction was developed as described for indirect ELISA. The results were expressed as percent of inhibition using the following formula: [Optical density (OD) in the absence of unlabelled antibody $\mathrm{OD}$ in the presence of unlabelled antibody $\times 100 / \mathrm{OD}$ in the absence of unlabelled antibody.

Immunoblotting analysis. This assay was performed by the method of Towbin et al. (1979) with slight modifications. Culture supernatants from CHSE-214 monolayers infected with IPNV instead of purified virus were used in the SDS-polyacrylamide gel electrophoresis (SDS-PAGE). Supernatants from uninfected CHSE-214 monolayers were used as control. The viral proteins were resolved in a $17 \%$ polyacrylamide gel by the method of Laemmli (1970). After electrophoresis, the gel was equilibrated with $20 \%$ methanol in $25 \mathrm{mM}$ Tris, $192 \mathrm{mM}$ glycine ( $\mathrm{pH} 8.3$ ). Proteins were electrophoretically transferred to a nitrocellulose membrane filter at a constant current of $500 \mathrm{~mA}$ for $1 \mathrm{~h}$ at $4{ }^{\circ} \mathrm{C}$, and the membrane was washed in $0.5 \mathrm{M} \mathrm{NaCl} 20 \mathrm{mM}$ Tris, pH 7.5 (TBS), dried, and cut into strips. The strips were incubated with TBS containing $2 \%$ nonfat dry milk (Molico, Nestle) for $1 \mathrm{~h}$ at $37^{\circ} \mathrm{C}$ and then incubated in a $1 / 20$ dilution of the ascites in TBS- $0.05 \%$ Tween 20 containing nonfat dry milk (TTBS) for $1 \mathrm{~h}$ at $37^{\circ} \mathrm{C}$. After washing in TTBS, the strips were incubated with a $1 / 1000$ dilution of a peroxidase conjugated goat-anti-mouse immunoglobulin in TTBS for $1 \mathrm{~h}$ at $37^{\circ} \mathrm{C}$. After washing with TTBS, the bands recognized by the Mabs were developed by the 4-chloro-naphthol technique (Hawkes et al. 1982).

\section{RESULTS}

\section{Assay characterization}

Among 9 Mabs obtained against the Sp strain of IPNV, we selected for diagnostic use the Mabs 3B12 and 2F12. These 2 Mabs are $\operatorname{IgG}_{2 a, k}$, and both react with the minor structural protein VP3 (29K) as determined by Western immunoblot analysis (Fig. 1). When tested by ELISA for cross-reaction with representative

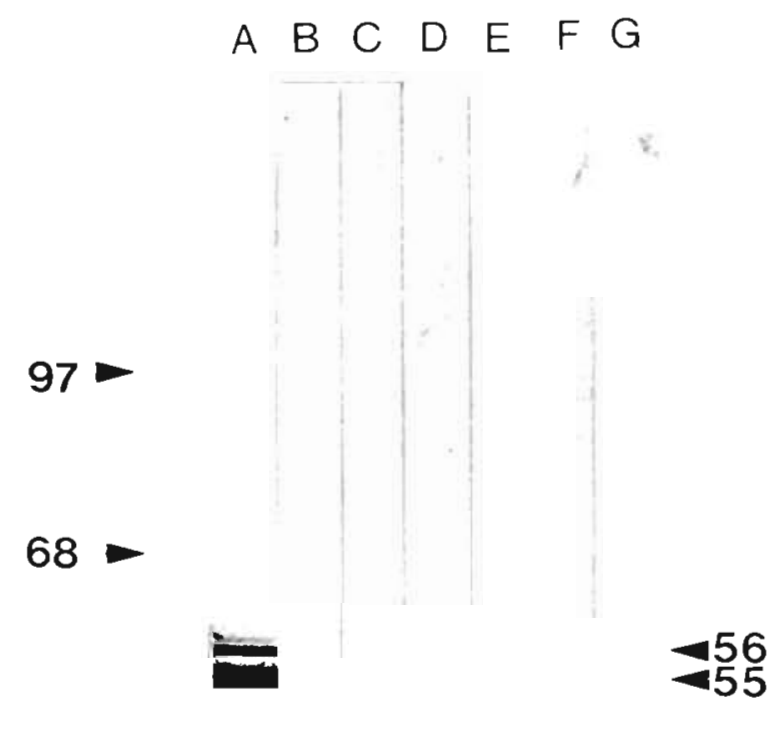

43

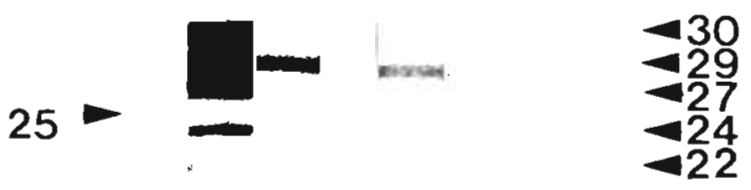

18

14

Fig. 1. Western immunoblot of the reaction of Mabs 3B12 and 2F12 with the IPNV proteins: (A) polyclonal anti-IPNV rabbit serum with IPNV-infected CHSE-214 cell culture supernatant; (B, C) Mab 2F12 with IPNV-infected and uninfected CHSE214 cell culture supernatant, respectively; (D, E) Mab 3B12 with IPNV-infected and uninfected CHSE-214 cell culture supernatant, respectively; $(F, G)$ irrelevant Mab (directed against trout immunoglobulin) with IPNV-infected and uninfected CHSE-214 cell culture supernatant, respectively. Nos. in right margin are molecular weight markers in $\mathrm{k} \mathrm{Da}$. Nos. in left margin represent estimated molecular weight of band 


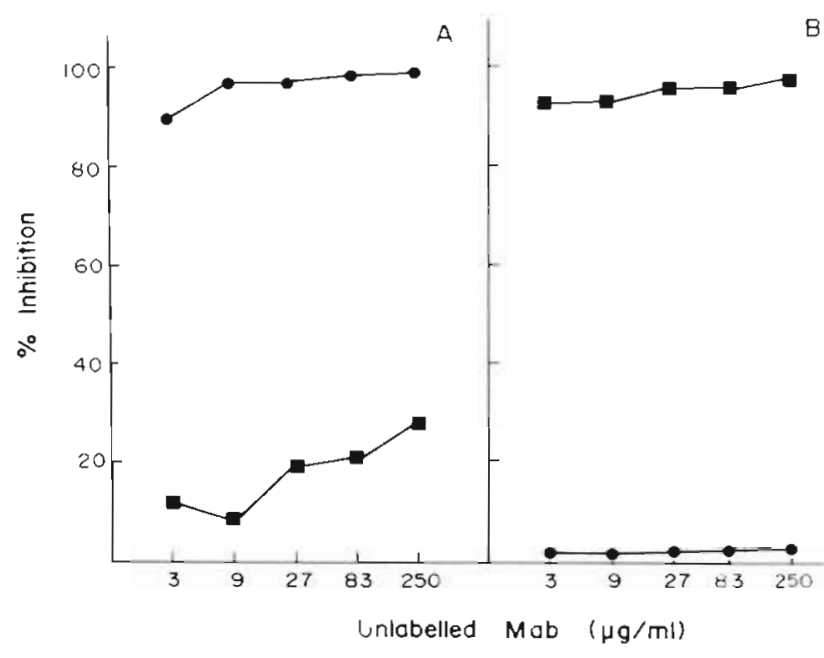

Fig. 2. Competitive binding of biotin-labelled 3B12 (A) or biotin-labelled 2F12 (B) with different amounts of unlabelled 3B12 $\bullet$ ) and 2F12 (-). Mabs were purified by affinity chromatography on Protein A Sepharose CL-4B (Pharmacia,

Sweden). For more details see 'Materials and methods'

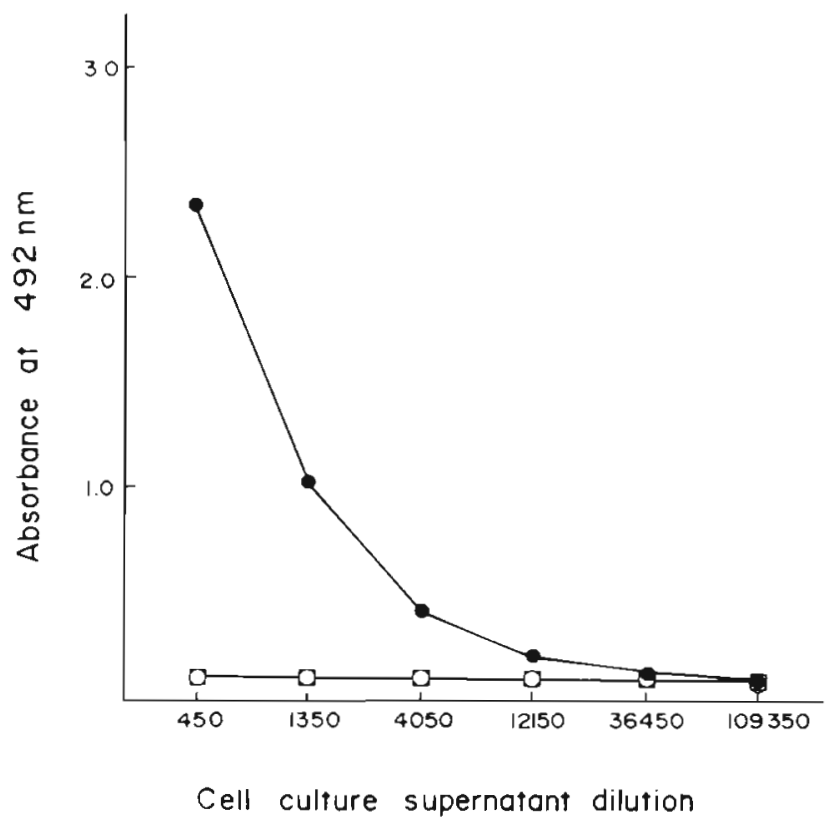

Fig. 3. Estimation of ELISA sensitivity by titration of IPNVinfected CHSE-214 cell culture supematant $(\bullet \bullet)$, VHSinfected EPC cell culture supernatant (-), and non-infected CHSE-214 cell culture supernatant (-). The undiluted IPNinfected cell culture supernatant contained $1.5 \times 10^{8} \mathrm{TCID}_{50}$ $\mathrm{ml}^{-1}$ and the undiluted VHS-infected cell culture supernatant contained $10^{7} \mathrm{TCID}_{50} \mathrm{mI}^{-1}$

members of serotypes $\mathrm{Ab}$ and $\mathrm{VR}_{299}$, Mab $2 \mathrm{~F} 12$ was broadly reactive with the 3 serotypes, whereas the Mab $3 \mathrm{~B} 12$ reacted only with the $\mathrm{Sp}$ isolate (data not shown).

The epitopes recognized by these Mabs were analyzed by a competition ELISA using plates coated

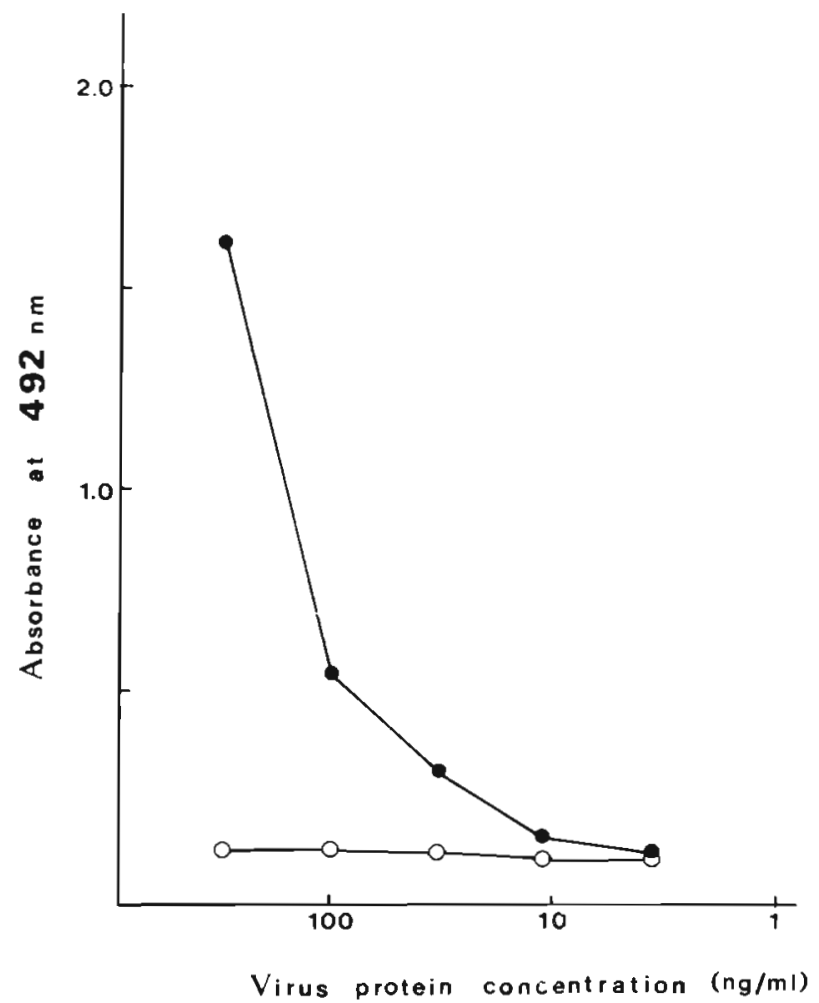

Fig. 4. Relationships between ELISA values $\left(\mathrm{A}_{492}\right)$ and virus protein concentration ( $\mathrm{ng} \mathrm{ml^{-1 }}$ ). Symbols represent purified IPN virus $(\bullet)$ and non-infected CHSE-214 cell culture supernatant $(0)$

with purified IPN virus. As shown in Fig. 2, these 2 Mabs did not compete for the same viral epitope. Rather, they reacted with 2 different and independent sites on the VP3.

Optimal concentrations and combinations of the first and second Mabs were determined by checkerboard titration. From these results, $2 \mu \mathrm{g} \mathrm{ml}^{-1}$ of Mab $3 \mathrm{~B} 12$ for coating plates and 1/1000 dilution of the biotin labelled 2 F12 were used in the following tests because these dilutions gave the strongest reactions with the lowest background.

The sensitivity of the ELISA was determined by testing dilutions of a stock Sp-IPNV infected cell culture supernatant containing $1.5 \times 10^{8} \mathrm{TCID}_{50} \mathrm{ml}^{-1}$. Levels of approximately $10^{4} \mathrm{TCID}_{50} \mathrm{ml}^{-1}$ were the minimum detectable by the ELISA (Fig. 3). The specificity of the ELISA was confirmed by the lack of reactivity with the uninfected cell culture fluid or VHS infected cell cultures.

The ELISA assay was not a strict indicator of virus concentration because it also reacted with non-infectious IPNV antigen present in the samples. For this reason, we also determined the protein concentration of purified virus detectable using the ELISA. Concentrations as low as $10 \mathrm{ng} \mathrm{ml^{-1 }}$ of purified antigen were detected (Fig. 4). 


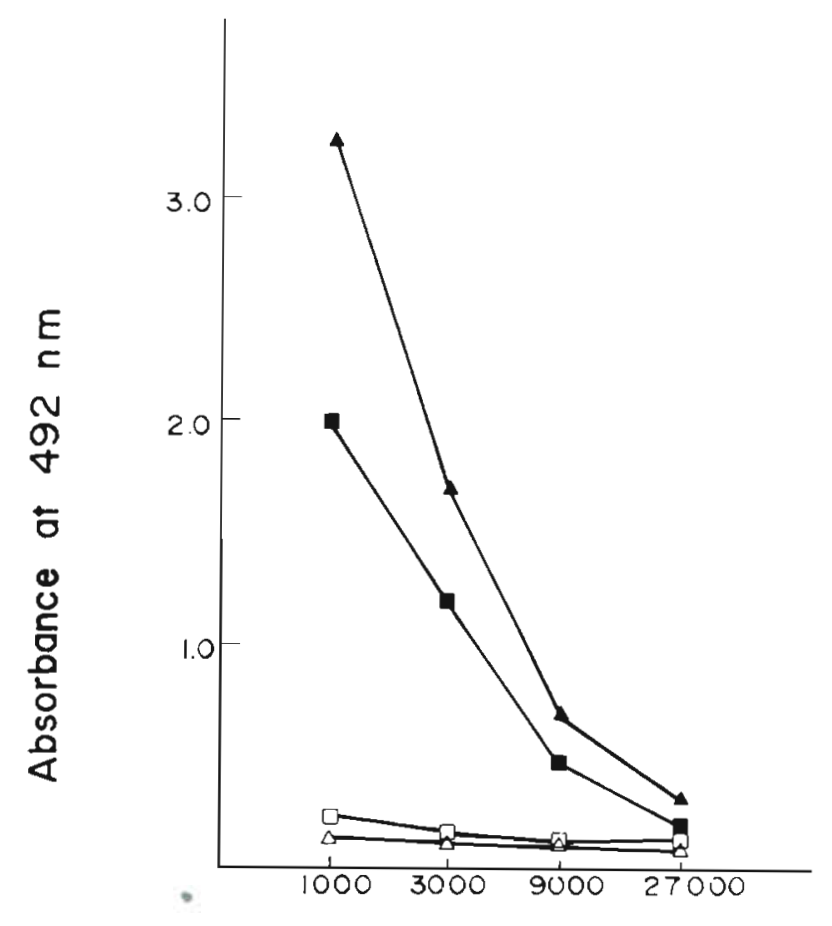

\section{Cell culture supernatant dilution}

Fig. 5. Comparison between 3-step ELISA assay $(\Delta, \Delta)$ and one-step assay $(\boldsymbol{\bullet}, \square)$. Filled symbols represent IPNV-infected CHSE-214 cell culture supernatant and open symbols represent non-infected CHSE-214 cell culture supernatant. The undiluted IPNV-infected cell culture supernatant contained $1.5 \times 10^{8} \mathrm{TCID}_{50} \mathrm{ml}^{-1}$

\section{One-step assay}

In order to reduce the time involved in carrying out the assay, the effect on sensitivity of the simultaneous incubation of labelled Mab and avidin-peroxidase conjugate with dilutions of the infected cell culture supernatants was investigated. A comparison of the results obtained with the one-step assay after $90 \mathrm{~min}$ incubation and with the 3-step assay is shown in Fig. 5. Although sensitivity of the one-step asay was slightly reduced with respect to the 3 -step assay, it yielded substantial OD values at virus dilutions close to $10^{4}$ TCID $50 \mathrm{ml}^{-1}$.

\section{Use of the assay}

The ELISA was evaluated for its ability to identify 17 different Spanish isolates of IPNV from infected CHSE214 supernatants. All isolates analyzed belonged to the Sp serotype as determined by seroneutralization and were collected over a period of $4 \mathrm{yr}$. As shown in
Table 1 Detection of Spanish IPNV isolates in cell culture supernatants by one-step assay after 90 and $30 \mathrm{~min}$ incubation. All the isolates were of the Sp serotype. Samples were tested at a 1/20 dilution. ND: Not determined

\begin{tabular}{|c|c|c|c|}
\hline \multirow[t]{2}{*}{ Isolate } & \multirow{2}{*}{$\begin{array}{c}\text { Titer } \\
\left(\mathrm{TClD}^{50} \mathrm{ml}^{-1}\right)\end{array}$} & \multicolumn{2}{|c|}{ OD at $492 \mathrm{~nm}$} \\
\hline & & $90 \mathrm{~min}$ & $30 \mathrm{~min}$ \\
\hline $128 / 85$ & ND & 0.707 & 0.261 \\
\hline $142 / 85$ & ND & 0.647 & 0.100 \\
\hline $26 / 86$ & $4 \times 10^{5}$ & 2.000 & 0.649 \\
\hline $42 / 86$ & $2 \times 10^{8}$ & 1.381 & 0.181 \\
\hline $140 / 86$ & $1 \times 10^{7}$ & 4.000 & 2.012 \\
\hline $215 / 86$ & $1 \times 10^{8}$ & 4.000 & 1.813 \\
\hline $377 / 86$ & ND & 2.472 & 1.014 \\
\hline $493 / 86$ & ND & 3.130 & 0.966 \\
\hline $520 / 86$ & ND & 2.000 & 1.346 \\
\hline $599 / 86$ & ND & 1.849 & 0.589 \\
\hline $281 / 87$ & ND & 0.433 & 0.040 \\
\hline $363 / 87$ & $1 \times 10^{5}$ & 4.000 & 2.078 \\
\hline $378 / 87$ & $3 \times 10^{7}$ & 4.000 & 2.000 \\
\hline $404 / 87$ & ND & 4.000 & 1.450 \\
\hline $1017 / 87$ & ND & 2.000 & 0.250 \\
\hline $1086 / 87$ & ND & 1.926 & 0.545 \\
\hline $442 / 88$ & ND & 2.000 & 1.304 \\
\hline IPN-Ab & $5 \times 10^{6}$ & 0.007 & 0.007 \\
\hline$I P N-V R_{299}$ & $5 \times 10^{6}$ & 0.008 & 0.007 \\
\hline \multicolumn{2}{|c|}{ Non-infected supernatant } & 0.004 & 0.002 \\
\hline
\end{tabular}

Table 1, all isolates were clearly identified by the onestep ELISA in $90 \mathrm{~min}$ and most of them were detected when the incubation was reduced to $30 \mathrm{~min}$.

The ability to detect virus in fish homogenates was tested by adding $7.5 \times 10^{6}$ TCID $_{50}$ to liver, spleen, and kidney from a $10 \mathrm{~cm}$ trout. The organs were homogenized in $5 \mathrm{ml}$ of maintenance medium using a Ten Broek unit. An equal amount of virus diluted in maintenance medium was used as control. The homogenates were centrifuged at $2000 \times g$ for $10 \mathrm{~min}$ and the supernatants tested by the 3-step ELISA. No interference due to the homogenized tissue was observed (Fig.6). Similar results were obtained by serially diluting 3 -fold the IPNV in homogenate supernatants and then mixing $1 / 1$ with the dilution buffer on the ELISA plates (data not shown).

\section{DISCUSSION}

ELISAs are being widely used for diagnosis of viral diseases because of their high sensitivity and because they permit the rapid processing of large numbers of samples. The use of ELISA for detection of IPNV has been reported by several, authors (Nicholson \& Caswell 1982, Dixon \& Hill 1983, Hattori et al. 1984, Rodack et al. 1988) with large differences in sensitivity between assays. These differences in sensitivity are most likely 


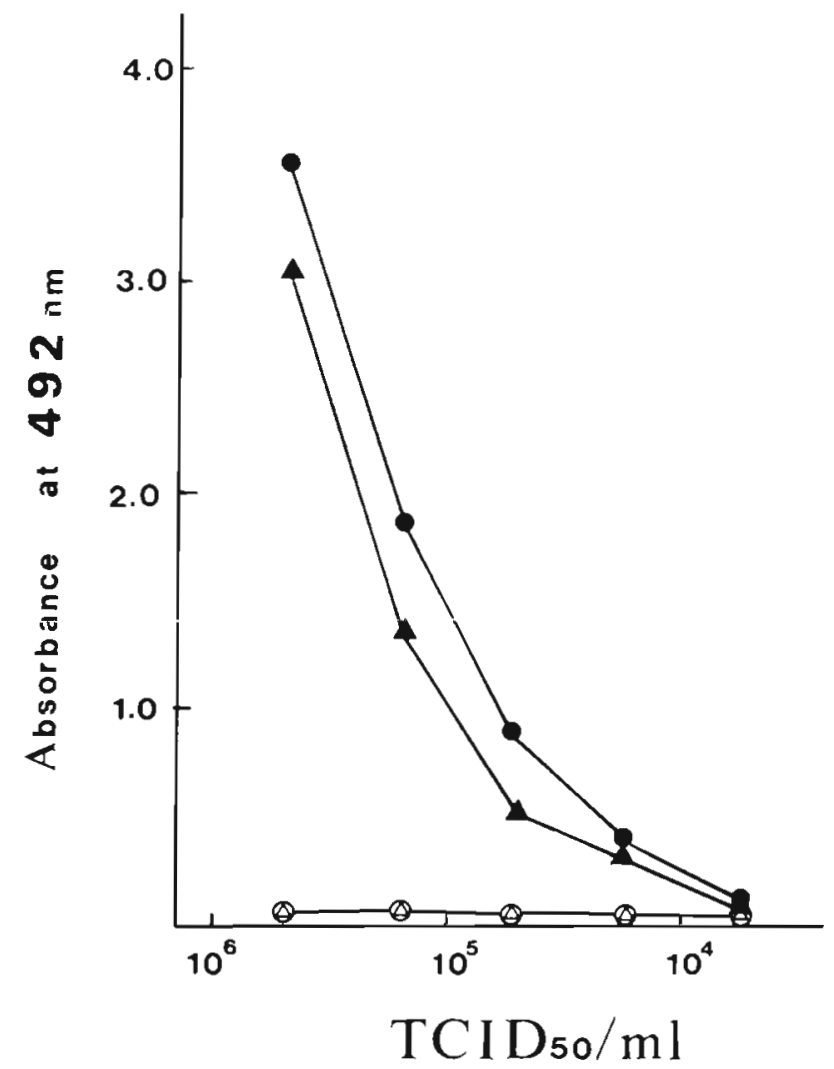

Fig. 6. ELISA detection of IPNV in organ homogenates: $7.5 \times$ $10^{6} \mathrm{TCID}_{50}$ of IPNV were added to trout liver, spleen, and kidney prior to homogenization $(\boldsymbol{\bullet})$, or to an equivalent volume of maintenance medium (•). The virus suspensions were then diluted with dilution buffer and assayed. Uninfected organ homogenate $(\Delta)$ or CHSE-214 cell culture supernatant (o) were used as controls

due to the quality of polyclonal antisera used and the presence of variable concentrations of non-infective viral particles in the samples tested.

The use of monoclonal antibodies that can be produced in large amounts with uniform quality will facilitate the standardization of these assays and make possible the direct comparison between results from different laboratories. In the present study we describe the use of 2 Mabs in a biotin-avidin amplified ELISA. These Mabs recognize 2 non-overlapping epitopes on the $29 \mathrm{~K}$ minor structural viral protein. Mab 2F12 reacts broadly with the representative isolates of the $\mathrm{Sp}, \mathrm{Ab}$, and $\mathrm{VR}_{299}$ serotypes, whereas Mab $3 \mathrm{~F} 12$ recognizes only the Sp serotype, the most pathogenic of the European serotypes (Jorgensen 1973). The epitopes recognized by these Mabs were present in all of the 17 Spanish isolates tested. Although more isolates should be analyzed in order to demonstrate the degree of conservation of these epitopes among the IPN viruses, the results obtained make these Mabs valuable reagents for IPN serotyping and diagnosis. Moreover, the combination of these Mabs with other serotype-specific Mabs that react with non-overlapping epitopes on the same protein could increase the accuracy of the assay and even improve its sensitivity as has been reported for other antigens (Ehrlich \& Moyle 1986).

This assay detects as little as $10 \mathrm{ng} \mathrm{ml}^{-1}$ of purified virus or $10^{4} \mathrm{TCID}_{50} \mathrm{ml}^{-1}$ infected cell cultures without interference from organ extracts. This sensitivity is similar to the ELISA reported by Hattori et al. (1984) and slightly lower than that claimed by Rodack et al. (1988); however it is sufficient to detect IPNV in infected fishes in which virus titer ranges from $10^{55}$ to $10^{5.8}$ (Yasutake et al. 1965). Because carrier fishes frequentiy show titers below the detectable limit of our assay, an initial increase of virus titer by cell culture incubation is necessary in these cases.

The co-incubation of the biotin-labelled Mab and the avidin peroxidase conjugate with the samples to be tested simplifies the assay. Visually positive results for most of the isolates could be obtained in as short a time as $30 \mathrm{~min}$, although in 2 cases more prolonged incubation (90 min) was necessary. The coated plates and the labelled reagents can be stored at $4^{\circ} \mathrm{C}$ for $1^{\prime \prime}$ mo without significant loss of sensitivity (data not shown). These characteristics make the test suitable for use in the field.

Acknowledgements. We are grateful to $\mathrm{C}$. Hernândez and $\mathrm{J}$. Bustos for technical assistance. This work was supported by US-Spain Joint Committee Grant number CCA-8510/064.

\section{LITERATURE CITED}

A.hne, W. (1981). Serological techniques currently used in fish virology. Dev. biol. Standard 49: 3-27

Bradford, M. (1979). A rapid and sensitive method for the quantitation of microgram quantities of protein utilizing the principle of protein-dye binding. Analyt. Biochem. 72: $248-254$

Coll, J. (1987). Injection of physiological saline facilitates recovery of ascitic fluids for monoclonal antibody production. J. Immun. Methods 104: 219-222

Dixon, P. F., Hill, B. J. (1983). Rapid detection of infectious pancreatic necrosis virus (IPNV) by the enzyme-linked immunosorbent assay (ELISA). J. gen. Virol. 64: 321-330

Ehrlich, P. H., Moyle, R. W. (1986). Ultrasensitive cooperative immunoassays with mixed monoclonal antibodies. Meth. Enzym. 121. 695-702

Ey, P. L., Prowse, S. J., Fenkin, C. R. (1978\}. Isolation of pure $\operatorname{IgG}_{1}, I_{g} G_{2 d}$ and $I g G_{2 b}$ immunoglobulins from mouse serum using Protein A-Sepharose. Immunochemistry 15: 429-436

Hattor, M., Kodama, H., Ishiguro, S., Honda, A., Mikami T., Izawa, H. (1984). In vitro and in vivo detection of infectious pancreatic necrosis virus in fish by enzyme-linked immunosorbent assay. Am. J vet. Res. 45: 1876-1879

Hawkes, R. Niday, E., Gordon, J. (1982). A Dot-immunobinding assdy for monoclonal and other antibodies. Analyt. Biochem. 119: 14.2-147

Hedrick, R. P., Okamoto, N., Sano, T., Fryer, J. L. (1983). Biochemical characterization of eel virus European. J. gen. Virol. 64: 1421-1426 
Hill, B. J., Way, K. (1988). Fish Health Section, American Fisheries Society. International Fish Health Conference, Vancouver, p. 151

Jimenez de la Fuente, J., Marcotegui, M. A., San Juan, M. Basurco, B. (1988). Diagnosis of viral diseases in salmonid farms in Spain. Bull. Eur. Ass. Fish Pathol. 271. 3-5

Jorgensen, P. E. V. (1973). The nature and biological activity of IPN virus neutralizing antibodies in normal and immunized rainbow trout (Salmo gairdneri). Arch. Gesammte Virusforsh. 42: $9-20$

Kimura, T., Yoshimizu, H., Yasuda, H. (1984). Rapid, simple serological diagnosis of infectious pancreatic necrosis by coagglutination test using antibody-sensitized staphylococci. Fish Pathol. 19: 25-33

Kohler, G., Milstein, C. (1975). Continuous cultures of fused cells secreting antibody of predefined specificity. Nature, Lond. 256: 495-497

Laemmli, U. K. (1970). Cleavage of structural proteins during the assembly of the head of bacteriophage T4. Nature, Lond. 227: 680-685

McAllister, P. E., Schill, W. B. (1986). Immunoblot assay: a rapid and sensitive method for identification of salmonid fish viruses. J. Wildl. Dis. 22: $468-474$

Nicholson, B. L., Henchal, E. A. (1978). Rapid identification of infectious pancreatic necrosis virus in infected cell cultures by immunoperoxidase techniques. J. Wildl. Dis. 14: 465-469

Nicholson, B. L., Caswell, P. (1982). Enzyme-linked immunosorbent assay for identification of infectious pancreatic necrosis virus. J. clin. Microbiol. 16: 469-472

Responsible Subject Editor: Dr T Evelyn, Nanaimo, B.C. Canada
Pilcher, K. S., Fryer, J. L. (1980). The viral diseases of fish: a review through 1978. CRC critical Rev. Microbiol. 7: $287-364$

Piper, D., Nicholson, B. L., Dunn J. (1973). Immunofluorescent study of the replication of infectious pancreatic necrosis virus in trout and Atlantic salmon cell cultures. Infection Immunity 8: 249-254

Rodack, L., Pospisil, Z., Tomanek, J., Vesely, T., Obr, T., Valicek, L. (1988). Enzyme-linked immunosorbent assay (ELISA) detection of infectious pancreatic necrosis virus (IPNV) in culture fluids and tissue homogenates of the rainbow trout, Salmo gairdneri Richardson. J. Fish Dis. 11: 225-235

Stahli, C., Staehelin, T., Miggiano, V (1983). Spleen cell analysis and optimal immunization for high-frequency production of specific hybridomas. Meth. Enzym. 92: 26-36

Towbin, H., Staehelin, T., Gordon, J. (1979). Electrophoretic transfer of proteins from gels to nitrocellulose sheets: procedure and some applications. Proc. nat. Acad. Sci. U.S.A. 76: 4350-4354

Yamamoto, T. (1975). Infectious pancreatic necrosis (IPN) virus carriers and antibody production in population of rainbow trout (Salmo gairdneri). Can. J. Microbiol. 21: 1343-1347

Yasutake, W. T., Parisot, T. J., Klontz, G. W. (1965). Virus disease of the Salmonidae in Western United States. II Aspects of pathogenesis. Ann. N.Y. Acad. Sci. 126: $520-530$

Manuscript first received: May 16, 1989

Revised version accepted: April 10, 1990 